Available online at www.sciencedirect.com

Science $\mathcal{W}$ Direct.

Forest Ecology and

Management

Forest Ecology and Management 199 (2004) 259Đ272

www.elsevier.com/locate/forecc

\title{
Spatial and temporal patterns of beetles associated with coarse woody debris in managed bottomland hardwood forests
}

\author{
Michael D. Ulyshen ${ }^{a,}$, James L. Hanula ${ }^{a}$, Scott Horn ${ }^{a}$, John C. Kilgo \\ Christopher E. Moorman ${ }^{c}$ \\ aUSDA Forest Service, Southern Research Station, 320 Green Street, Athens, GA 30602-2044, USA \\ bUSDA Forest Service, Southern Research Station, Savannah River Site, P.O. Box 700, New Ellenton, SC 29809, USA \\ 'Department of Forestry, NC State University, Box 8003, 3028E Biltmore Hall, Raleigh, NC 27695-8003, USA
}

Received 7 A pril 2004; received in revised form 6 May 2004; accepted 13 May 2004

\begin{abstract}
Malaise traps were used to sample beetles in artipcial canopy gaps of different size ( $0.13 \mathrm{ha}, 0.26 \mathrm{ha}$, and $0.50 \mathrm{ha})$ and age in a South Carolina bottomland hardwood forest. Traps were placed at the center, edge, and in the surrounding forest of each gap. Young gaps ( 1 year) had large amounts of coarse woody debris compared to the surrounding forest, while older gaps ( 6 years) had virtually none. The total abundance and diversity of wood-dwelling beetles (B uprestidae, Cerambycidae, B rentidae, B ostrichidae, and Curculionidae (Scolytinae and Platypodinae)) was higher in the center of young gaps than in the center of old gaps. The abundance was higher in the center of young gaps than in the surrounding forest, while the forest surrounding old gaps and the edge of old gaps had a higher abundance and diversity of wood-dwelling beetles than did the center of old gaps. There was no difference in wood-dwelling beetle abundance between gaps of different size, but diversity was lower in 0.13 ha old gaps than in 0.26 ha or 0.50 ha old gaps. We suspect that gap size has more of an effect on woodborer abundance than indicated here because malaise traps sample a limited area. The predaceous beetle family Cleridae showed a very similar trend to that of the woodborers. Coarse woody debris is an important resource for many organisms, and our results lend further support to forest management practices that preserve coarse woody debris created during timber removal.
\end{abstract}

\# 2004 Elsevier B.V. All rights reserved.

Keywords: Coarse woody debris; Saproxylic; Woodborers; Cerambycidae; B uprestidae; B ark beetles; Cleridae

\section{Introduction}

Coarse woody debris (CWD) provides food and habitat for many animal species and can be a longterm source of nutrients for both plants and animals (Harmon et al., 1986; Hagan and Grove, 1999). Elton (1966) considered it to be one of the three greatest resources for animal species in natural forests and

\footnotetext{
${ }^{*}$ Corresponding author.

E-mail address: mulyshen@ hotmail.com (M.D. Ulyshen).
}

Huston (1996) claimed that CWD has a greater impact on biodiversity than does any other manageable forest property. B ecause of its documented value and the fact that it is likely to have other functions in ecosystems yet to be discovered, management of CWD is an increasingly important consideration for industrial and public forests (Harmon et al., 1986).

That beetles associated with dead and dying wood typically increase in abundance following logging operations has long been known. For example, in his 12 years collecting beetles in the tropics, Wallace 
(1869) found recent clearings to be the most productive areas for collecting cerambycids and other woodborers. The large amounts of CWD created by timber removal is short-lived, however, and is followed by extended periods without replacement until the regenerating forest enters the stem exclusion stage (Hagan and Grove, 1999). How the relative abundance of wood-dwelling beetles changes with time in these disturbed areas is not well understood.

We consider six families of beetles: Buprestidae, Cerambycidae, Bostrichidae, Brentidae (genus Arrhenodes), and Curculionidae (subfamilies Scoytinae and Platypodinae) all generally depend on dead or dying wood, and Cleridae ("checkered beetles") are predaceous on the adults and larvae of many bark and woodboring beetles.

Among the inhabitants of CWD, some of the most conspicuous are woodborers belonging to the families Cerambycidae and Buprestidae. While some feed on living trees, most are found on dead or dying wood (Bellamy and Nelson, 2002; Warriner et al., 2002; Fellin, 1980; Solomon, 1995). Some species are very host specific while others, largely those that feed on dead wood, tend to have wide host ranges (Yanega, 1996). Many species show specificity for such factors as bark thickness, height, and branch diameter which reduces competition between species thereby increasing diversity on a single resource (Yanega, 1996; Hanula, 1996; Bellamy and Nelson, 2002). Some species also prefer certain stages of decay. As decomposition proceeds, wood undergoes a series of chemical changes and experiences a predictable succession of cerambycid species over time (Linsley, 1961). Logs infested by members of these families can be completely degraded, resulting in reduced timber value (Barbosa and Wagner, 1989). Despite these negative aspects, woodboring beetles may play an important role in nutrient cycling by breaking down dead wood.

Scolytinae and Platypodinae are often the first to arrive at fresh CWD. Scolytines can be either true bark beetles, feeding on the inner phloem of wood, or ambrosia beetles (as are all platypodines), feeding on cultivated "ambrosia" fungi that grows in their tunnels (Solomon, 1995). Most scolytines and platypodines prefer dying or freshly fallen trees, but some also attack healthy trees, and all require sufficiently moist wood for proper larval development (Solomon, 1995; Anderson, 2002).
Brentids and bostrichids are few in numbers compared to the other woodborers, but they have similar lifecycles. Bostrichids typically infest dead trees but some can attack living trees that have been weakened (Fisher, 1950; Solomon, 1995). Because of their ability to attack dry wood, such as standing dead trees, bostrichids are able to infest wood that other woodborers find unusable (Hanula, 1996). Adult brentids can be found under dead bark and lay eggs in dying or recently fallen hardwoods after which their larvae burrow deep into the heartwood (Anderson and Kissinger, 2002).

Cleridae is a small family of mostly predaceous beetles (Opitz, 2002). Some species are considered important biocontrol agents against certain scolytines and important for forest health (Reeve, 2000; Cronin et al., 2000; Erbilgin and Raffa, 2002). Many host plant volatiles, such as alpha-pinene and ethanol, attract cerambycids, scolytines, and platypodines to stressed or dying trees (Anderson, 2002; Schroeder, 1988; Montgomery and Wargo, 1983). Clerids, in turn, use these chemicals and others, such as aggregation pheromones, in their search for prey (Schroeder, 1988; Montgomery and Wargo, 1983). Many of the clerid genera we collected are known to feed on one or several of the woodborer families considered in this study (Opitz, 2002).

This study was part of a larger study examining the effects of tree harvest gap size and age on arthropod and bird communities in managed southeastern bottomland hardwood forests. We report here the response of bark and woodborers to the creation of canopy gaps of different size and age. The gaps were created by group selection harvesting, an uneven-aged silvicultural practice that removes patches of desirable trees to create small $(<0.55 \mathrm{ha})$ openings similar to those created by insect infestations, severe wind damage, and other localized disturbances (Hunter, 1990; Meadows and Stanturf, 1997; Guldin, 1996). Forest management that fails to mimic natural rates and patterns of disturbance may disrupt the dead-wood dynamics of a forest which can result in extinctions of species adapted to the natural abundance and diversity of CWD (Grove, 2002). For example, years of intensive forest management has already extirpated or threatened numerous species throughout Europe (Grove, 2002; Twinn and Harding, 1999; Shirt, 1987). Group selection harvesting may be well suited for southeastern bottomland 
hardwood forest management because these forests are naturally adapted to similar small-scale disturbances.

\section{Methods}

\subsection{Study site}

The Savannah River Site (SRS) near Aiken, SC, is located in the upper Atlantic Coastal Plain Province. The SRS is an 80,269-ha nuclear production facility owned and operated by the United States Department of Energy (DOE). The SRS is a DOE National Environmental Research Park.

Our study was conducted on 120 ha of 75 -year-old bottomland hardwoods (Kilgo, 1997). Common overstory species included bald cypress (Taxodium distichum (L.) Richard), laurel oak (Quercus laurifolia Michaux), willow oak ( $Q$. phellos L.), overcup oak ( $Q$. lyrata Walter), cherrybark oak (Q. falcata var. pagodaefolia Ell.), swamp chestnut oak ( $Q$. michauxii Nuttall), sweetgum (Liquidambar styraciflua L.), red maple (Acer rubrum L.), and loblolly pine (Pinus taeda L.). The midstory consisted predominantly of red mulberry (Morus rubra L.), ironwood (Carpinus caroliniana Walter) and American holly (Ilex opaca Aiton). The understory was dominated by dwarf palmetto (Sabal minor (Jacquin) Persoon) and switchcane (Arundinaria gigantean (Walter) Muhl.). Preharvest basal area of the stands was $33 \mathrm{~m}^{2} /$ ha (Pauley et al., 1996). The stands typically experienced seasonal flooding leaving some of the lower-lying areas under water throughout much of the year. The total rainfall for the 2001 collecting season was $103.99 \mathrm{~cm}$, with the wettest month being June $(23.37 \mathrm{~cm})$, and the driest being December $(1.17 \mathrm{~cm})$. Significant portions of the study area were flooded from late January through early to mid-April.

\subsection{Canopy gaps}

Twenty-four gaps were used in this study. Twelve were created in December 1994 ("old gaps") and 12 in August 2000 ("new gaps"). Both old and new gaps were of three different sizes $(0.13 \mathrm{ha}, 0.26 \mathrm{ha}$, and $0.50 \mathrm{ha})$, each replicated four times. The gaps were entirely cleared of all trees (primarily oaks (Quercus spp.)) and other standing vegetation, and they encom- passed the area defined by the boles of perimeter trees. Most coarse woody debris was logging "slash" (tops, malformed boles, dead wood) that was left behind (Fig. 1).

At the time of sampling, the vegetation in the old gaps ranged from 1-8 $\mathrm{m}$ in height and consisted primarily of sweetgum, sycamore (Platanus occidentalis L.), green ash (Fraxinus pennsylvanica Marshall), black willow (Salix nigra Marshall), tulip poplar (Liriodendron tulipifera L.), blackberries (Rubus spp.), oaks, switchcane, and dwarf palmetto. Vegetation in the new gaps was up to $1 \mathrm{~m}$ tall and consisted primarily of, in addition to many listed above, fireweed (Erechtites hieracifolia (L.) Raf.), plumegrass (Erianthus giganteus (Walter) Muhl.), sedges (Cyperus spp.), and many native grass species.

\subsection{Beetle sampling}

A malaise trap was placed in the center of each gap (Fig. 1), at the gap edge, and $50 \mathrm{~m}$ into the forest from each gap. Traps were operated for four 1-week intervals (17-23 May, 10-16 July, 7-13 September, and 3-9 November) during 2001. The traps (Sante Traps, Lexington, $\mathrm{KY}$ ) differed from traditional malaises traps in that beetles could enter them from any direction and they had collecting jars at both the top and bottom so species that respond to barriers by dropping instead of flying upward were also captured. Traps were suspended from $3 \mathrm{~m}$ tall poles constructed from EMT electrical conduit. One lower corner of the trap was connected to the conduit pole to hold the trap in place during windy conditions. To further ensure the stability of the trap, the hanger was inserted into a larger pipe which had been driven in the ground. Poles were simply removed from the pipe to lower the trap for sample collecting. Collecting jars contained a $\mathrm{NaCl}-2 \%$ formaldehyde solution to preserve specimens and a drop of detergent to reduce surface tension (New and Hanula, 1998). Samples were immediately stored in $70 \%$ alcohol until they were identified to morphospecies.

\subsection{Coarse woody debris measurements}

We estimated the amount of CWD (stumps, logs, branches, and twigs of all sizes) left in the new gaps following logging (Fig. 1). The ground cover (i.e., plants, CWD, bare soil, etc.) was recorded every 


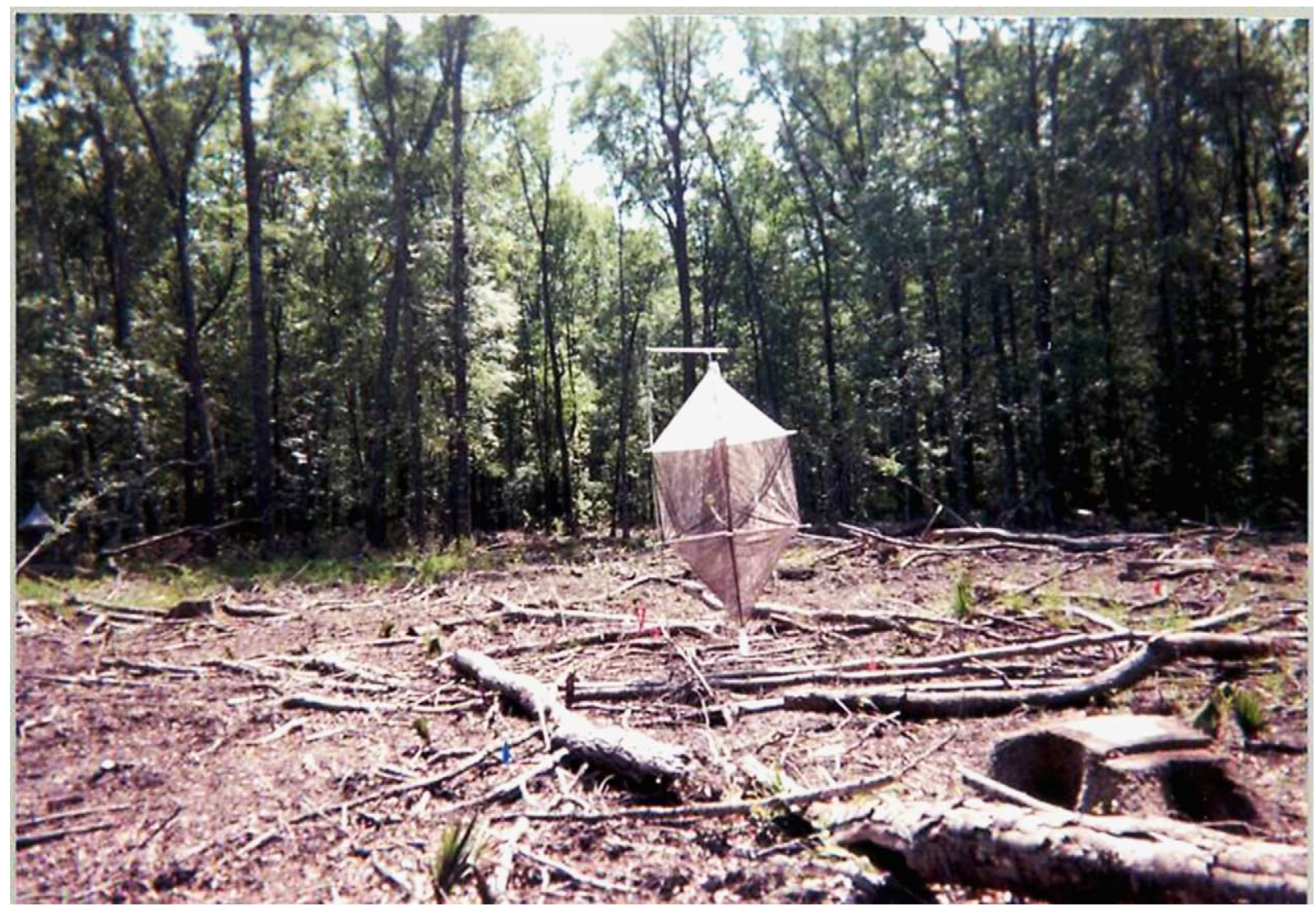

Fig. 1. The malaise trap (Sante Traps, Lexington, KY) used to sample bark and wood-boring beetles in a 0.50-ha canopy gap in a South Carolina bottomland hardwood forest. Note the large amounts of coarse woody debris created during timber removal.

$15 \mathrm{~cm}$ along 50-m transects through the center of each gap, and a percentage of each was recorded.

We did not quantify the amount of CWD in the old gaps but very little remained from when the gaps were created, and the thicket of young saplings growing there produced very little new woody debris. The surrounding forest had natural amounts of CWD in various stages of decay.

\subsection{Statistical analysis}

A three-way ANOVA with gap age, trap location, and gap size as the main effects showed a significant interaction between gap age and location so we analyzed the data for each gap age separately.

The square-root transformation was used to satisfy assumptions of normality and homogeneity of variance where appropriate. Data were analyzed using the
General Linear Models procedure of SAS (SAS Institute, 1985), and the Ryan-Einot-Gabriel-Welsch Multiple Range Test was used to determine differences in relative abundances of insects between trap locations or gap sizes for each gap age (Day and Quinn, 1989). Statistical significance was accepted when $\alpha \leq 0.05$. All differences mentioned in the text are significant unless otherwise stated.

\section{Results}

\subsection{Coarse woody debris}

We determined that nearly one fourth $(23.58 \%$, $n=12$ ) of the ground in the new gaps was covered by coarse woody debris. The amount of CWD was fairly consistent for all gap sizes $(20.75 \%, 27.5 \%$, and 
$22.5 \%$ for 0.13 ha, 0.26 ha, and 0.50 ha gaps, respectively).

\subsection{Overall beetle diversity and abundance}

We collected 3122 specimens representing 126 species of bark and woodboring beetles (Table 1). Scolytinae was by far the most abundant group and only slightly less diverse than Cerambycidae (Table 1). Clerids were also well represented with 16 species and 376 specimens collected. Only nine specimens of three species of bostrichids were collected, making this the least abundant family in our samples (Table 1).

\subsection{Influence of gap age on bark beetles and woodborers}

Regardless of gap size or location, the total abundance and richness of all woodborers was higher in new gaps than in old gaps (Figs. 2 and 3). Similar trends existed for individual families or subfamilies. There were higher numbers of all groups in the centers of new gaps versus the centers of old gaps (Fig. 4). With the exception of Cerambycidae (Fig. 4B), we collected more specimens of each group at the edge of the new gaps than at the edge of old gaps (Fig. 4). Only Scolytinae (Fig. 4D) were more abundant in the forest surrounding the new gaps than around the old gaps.

We analyzed eight of the most common $(\geq 10$ individuals collected) cerambycid species individually. Except for Neoclytus sp. 3 (Fig. 5F), all were more numerous in new gap centers than old (Fig. 5).
All but two species (Fig. 5D and G) were more numerous at the edge of new gaps than the edge of old gaps, and there were no significant differences between the number of beetles captured in the forest around new and old gaps (Fig. 5).

Three species of Buprestidae were captured in high enough numbers to allow comparisons among treatments (Fig. 6). Of those, two (Fig. 6B and C) were more abundant in new gap centers than old gap centers. Agrilus sp. 1 was more abundant in the forest around new gaps than around old, but the abundance of this species was very low at the edges of new gaps (Fig. 6).

The scolytine species Hypothenemus sp. 2 and Xyleborinus $s p .2$ were captured in higher numbers in the centers and edges of new gaps than of old (Fig. 7). Xyleborinus sp. 2 also was more abundant in the forest surrounding the new gaps than the old (Fig. 7B).

\subsection{Influence of trap location on bark beetles and woodborers}

\subsubsection{New gaps}

In total, woodborers were more abundant at the gap center and edge than in the nearby forest (Fig. 2A). While species richness shows a similar trend, the differences between the locations is not significant. Buprestids, cerambycids, brentids, and clerids were all captured in higher numbers in gap centers than at the edges or in the nearby forest (Fig. 4A, B, E and F). Platypodines and scolytines were both more abundant at the edge than in the forest (Fig. 4C and D), and traps at the gap centers had fewer platypodines than at

Table 1

Total number/richness of six beetle families collected in malaise traps set at gap center, gap edge, and nearby forest of canopy gaps created in 1994 and 2000 in a hardwood bottomland forest at the Savannah River Site, South Carolina

\begin{tabular}{|c|c|c|c|c|c|c|c|}
\hline & \multicolumn{3}{|c|}{2000 treatment } & \multicolumn{3}{|c|}{1994 treatment } & \multirow[t]{2}{*}{ Total } \\
\hline & Center & Edge & Forest & Center & Edge & Forest & \\
\hline Buprestidae & $421 / 12$ & $70 / 12$ & $45 / 9$ & $25 / 5$ & $17 / 6$ & $23 / 6$ & $601 / 17$ \\
\hline Cerambycidae & $546 / 34$ & $272 / 29$ & $187 / 26$ & $19 / 13$ & $57 / 19$ & $55 / 22$ & $1136 / 51$ \\
\hline Bostrichidae & $4 / 3$ & $3 / 1$ & $1 / 1$ & 0 & $1 / 1$ & 0 & $9 / 3$ \\
\hline Brentidae (Arrhenodes) & $42 / 1$ & $11 / 1$ & $2 / 1$ & 0 & $1 / 1$ & $2 / 1$ & $58 / 1$ \\
\hline Curculionidae (Platypodinae) & $11 / 2$ & $26 / 3$ & $6 / 1$ & $2 / 1$ & $5 / 2$ & $6 / 3$ & $56 / 5$ \\
\hline Curculionidae (Scolytinae) & $451 / 18$ & $839 / 21$ & $227 / 30$ & $35 / 12$ & $131 / 24$ & $120 / 24$ & $1803 / 49$ \\
\hline Total woodborer & $1475 / 70$ & $976 / 67$ & $468 / 68$ & $81 / 31$ & $212 / 53$ & $206 / 56$ & $3122 / 126$ \\
\hline Cleridae & 205/12 & $61 / 12$ & $44 / 11$ & $7 / 3$ & $21 / 7$ & $38 / 10$ & $376 / 16$ \\
\hline
\end{tabular}

Samples were collected from May to November 2001. 


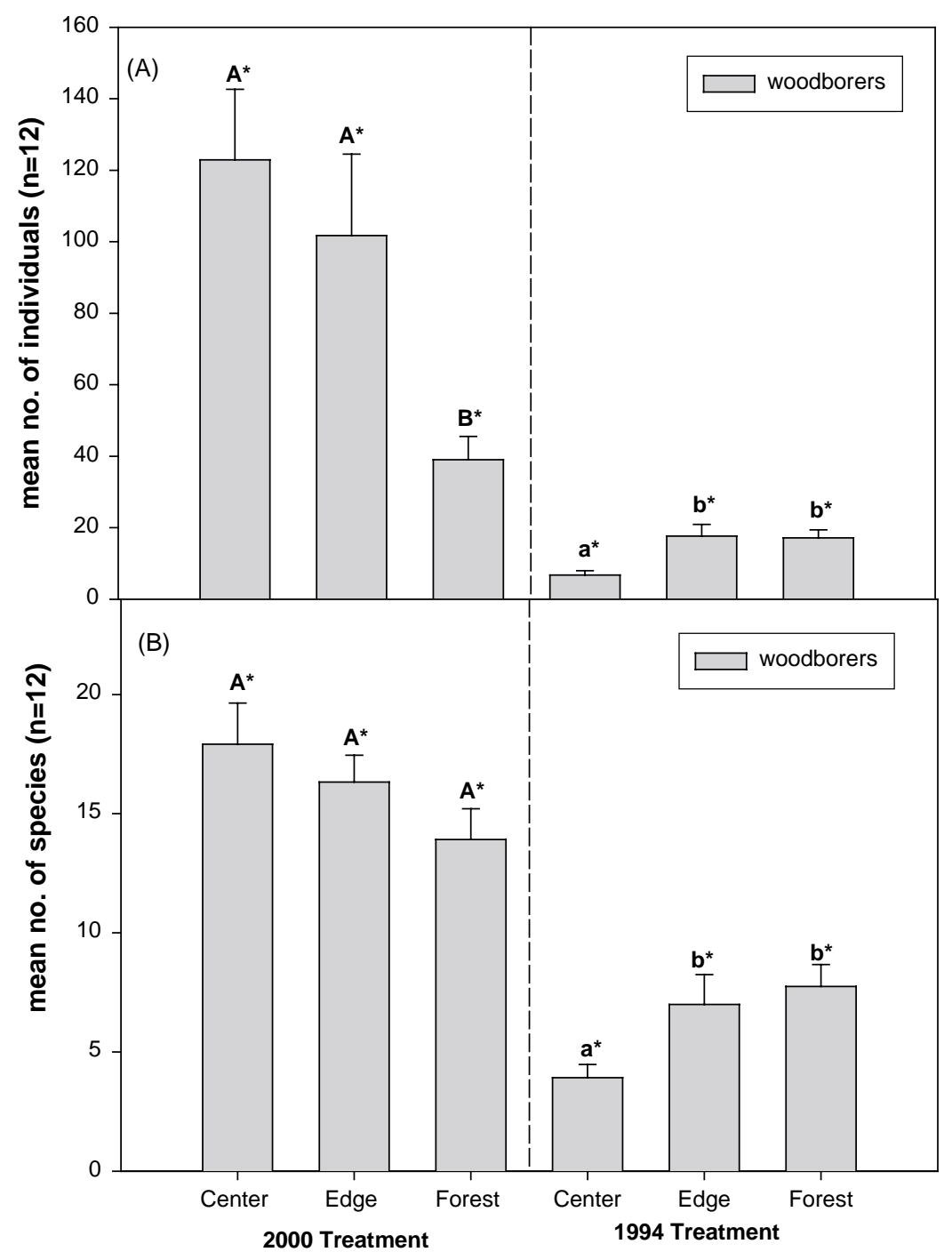

Fig. 2. Mean ( \pm S.E.) abundance and richness of woodboring beetles (Cerambycidae, Buprestidae, Bostrichidae, Brentidae (Arrhenodes), Curculionidae (Platypodinae and Scolytinae)) captured in malaise traps at different locations in bottomland hardwood forest gaps created in 1994 and 2000. Within graphs, bars with the same letter above them are not significantly different (Ryan-Einot-Gabriel-Welsch Multiple Range Test, $P<0.05)$. Asterisks denote significant differences $(P<0.05)$ between the same trap locations (e.g., center vs. center) in old $(1994)$ and new (2000) gaps.

the edges (Fig. 4C). Of the 16 genera we studied individually, only four did not differ in abundance among locations in the new gaps (Figs. 5F-H and 7B).

\subsubsection{Old gaps}

In the old gaps, we captured more individuals and species of woodborers at the edge and in the forest than at gap center (Fig. 2). Cerambycids and scolytines were more abundant at the edge and in the forest than in the center of old gaps (Fig. 4B and D). Clerids were more abundant in the forest than at gap center (Fig. 4F). Among individual genera, only the cerambycid Neoclytus sp. 3 (Fig. 5F) differed among locations. 


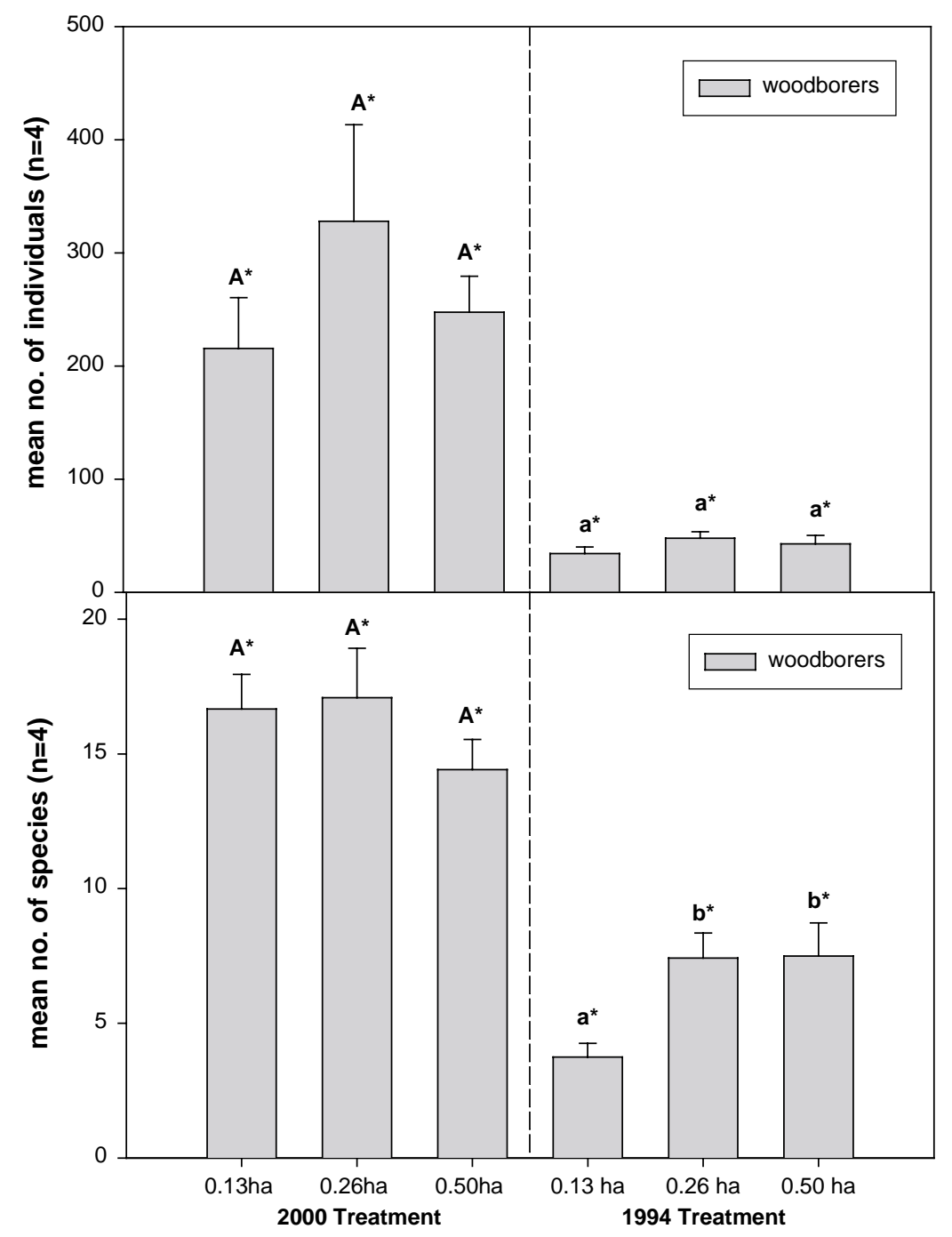

Fig. 3. Mean ( \pm S.E.) abundance and richness of woodboring beetles (Cerambycidae, Buprestidae, Bostrichidae, Brentidae (Arrhenodes), Curculionidae (Platypodinae and Scolytinae)) captured in malaise traps in bottomland hardwood forest gaps of different sizes created in 1994 and 2000. The three malaise samples (a trap was placed at the center, edge, and in nearby forest for each gap) were combined for these results. Within graphs, bars with the same letter above them are not significantly different (Ryan-Einot-Gabriel-Welsch Multiple Range Test, $P<0.05$ ). Asterisks denote significant differences $(P<0.05)$ between the same trap locations (e.g., center vs. center) in old (1994) and new (2000) gaps.

\subsection{Influence of gap size on bark beetles and woodborers}

The different gap sizes had less of an effect on woodborers than did trap location. Except for lower richness in 0.13 ha old gaps than in 0.26 ha or 0.50 ha old gaps, there was no significant difference in total bark-beetle and woodborer diversity or abundance in gaps of different size (Fig. 3).

\subsection{Response of Cleridae}

The trend among clerids closely matched that of their prey. Clerids were more abundant in the center of new gaps than at the edge or in the forest (Fig. 4F). They also were more abundant at the center and edge of new gaps than in old, and were less abundant in the center of old gaps than in the surrounding forest (Fig. 4F). Neorthopleura thoracica and Chariessa 


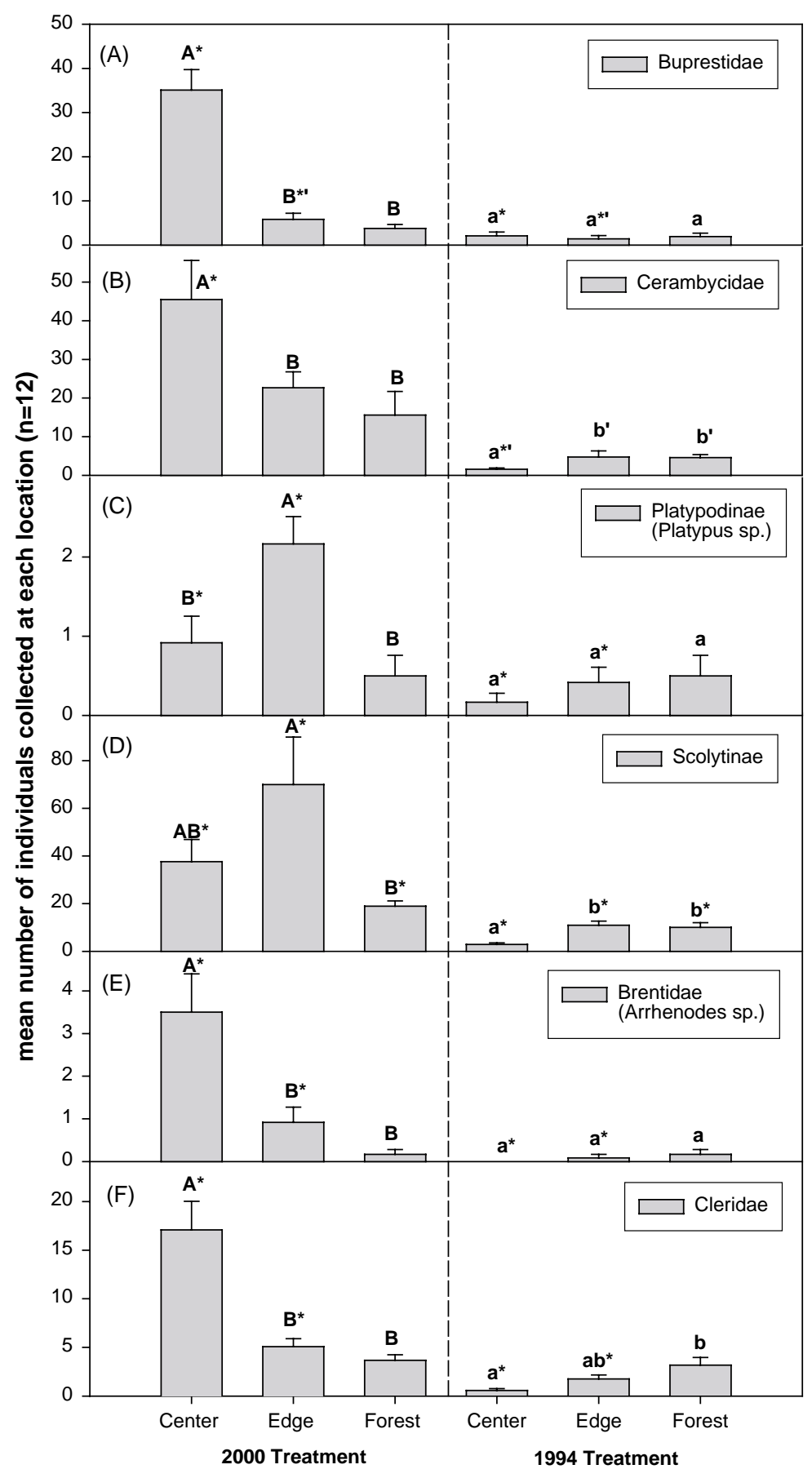

Fig. 4. Mean ( \pm S.E.) abundance of woodboring beetles (at family or genus level) captured in malaise traps at different locations in bottomland hardwood forest gaps created in 1994 and 2000. Within graphs, bars with the same letter above them are not significantly different (RyanEinot-Gabriel-Welsch Multiple Range Test, $P>0.05)$. Asterisks denote significant differences $(P<0.05)$ between the same trap locations (e.g., center vs. center) in old (1994) and new (2000) gaps. The prime symbol indicates the data were transformed using the square root transformation prior to analysis. 


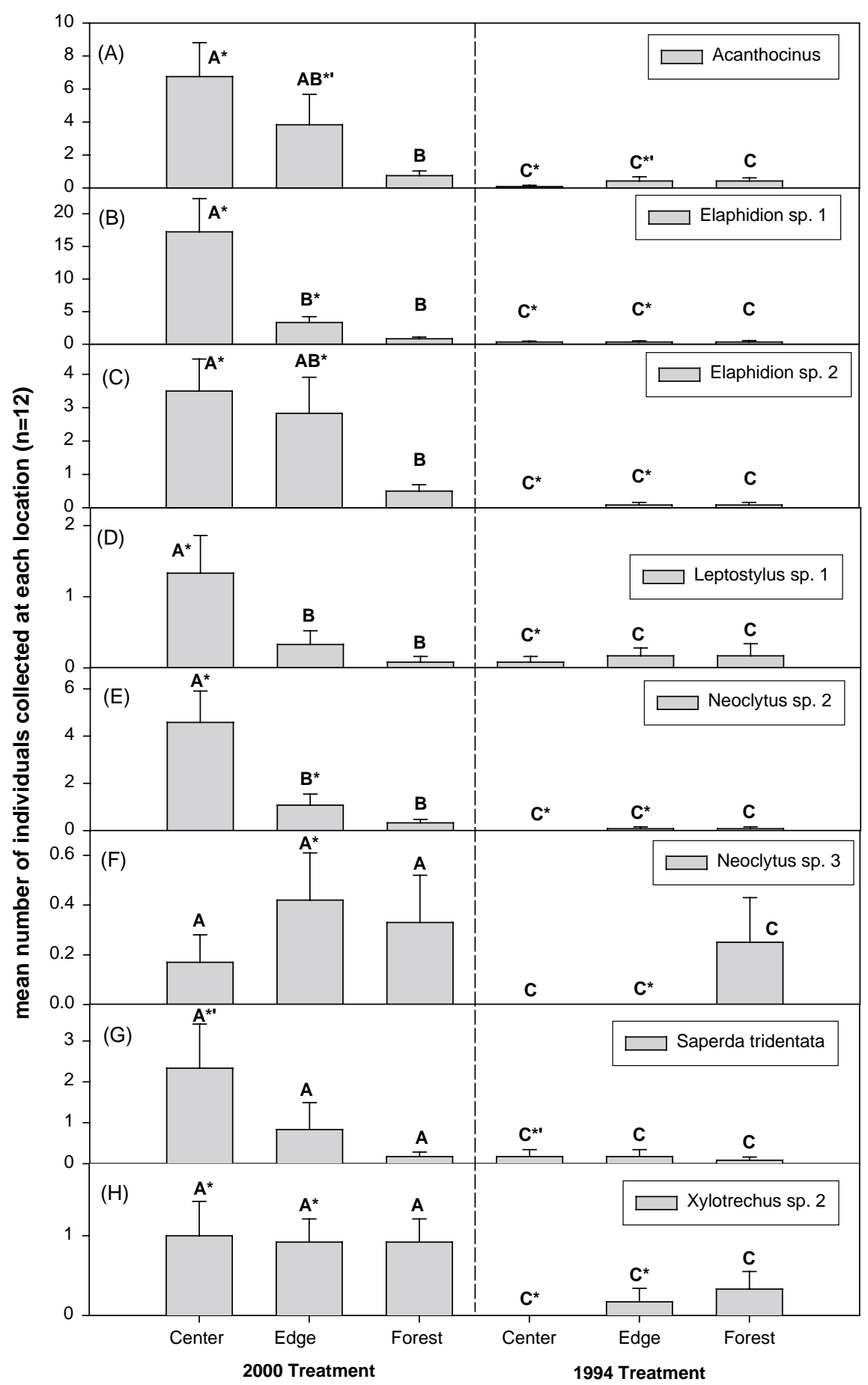

Fig. 5. Mean ( \pm S.E.) abundance of notable cerambycid species captured in malaise traps at different locations in bottomland hardwood forest gaps created in 1994 and 2000. Within graphs, bars with the same letter above them are not significantly different (Ryan-Einot-Gabriel-Welsch Multiple Range Test, $P>0.05)$. Asterisks denote significant differences $(P<0.05)$ between the same trap locations (e.g., center vs. center) in old (1994) and new (2000) gaps. The prime symbol indicates the data were transformed using the square root transformation prior to analysis. 


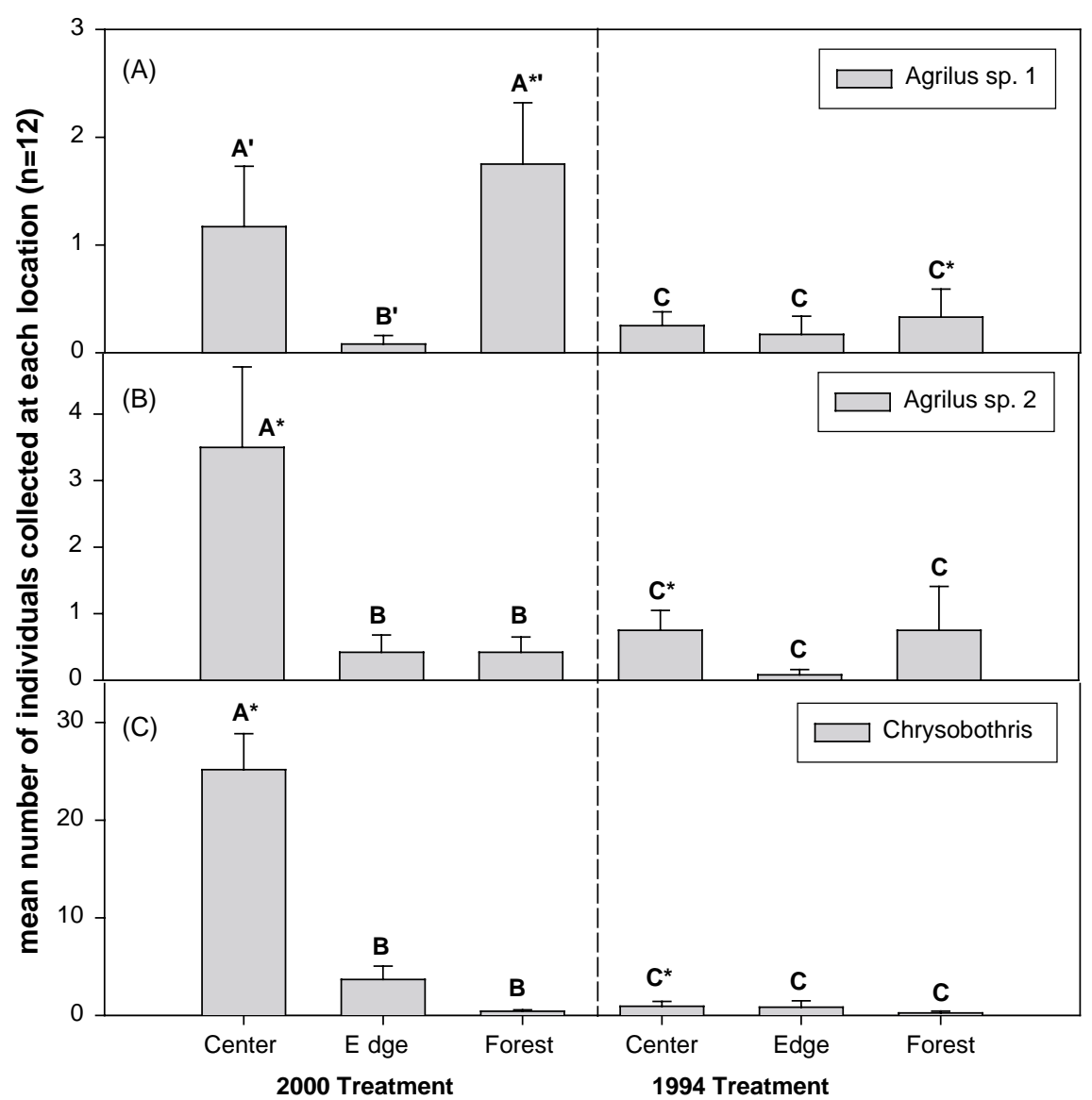

Fig. 6. Mean $( \pm$ S.E. $)$ abundance of notable buprestid species captured in malaise traps at different locations in bottomland hardwood forest gaps created in 1994 and 2000. Within graphs, bars with the same letter above them are not significantly different (Ryan-Einot-Gabriel-Welsch Multiple Range Test, $P>0.05)$. Asterisks denote significant differences $(P<0.05)$ between the same trap locations (e.g., center vs. center) in old (1994) and new (2000) gaps. The prime symbol indicates the data were transformed using the square root transformation prior to analysis.

pilos were the most numerous species and they closely matched the trend for the entire family (Fig. 8). Cregya oculata was more abundant in traps located in new gap centers and edges than in those located at similar positions in old gaps (Fig. 8). Neorthopleura thoracica (Fig. 8C) and Chariessa pilos (Fig. 8A) differed among locations in old gaps.

\subsection{Specialist species}

Of all families considered, 14 species were collected only in the center of new gaps. Of these, only 2 (Chalcophora (Buprestidae) and Ecyrus (Cerambycidae)) were abundant enough (27 and 15 individuals, respectively) to consider as possible gap specialists.
While other species were only collected in certain locations, they were not collected in high enough numbers to determine that they may specialize in such areas.

\section{Discussion}

The importance of preserving CWD for wooddwelling beetle communities is well supported by past research. For example, Warriner et al. (2002) saw increased cerambycid diversity and abundance in recently thinned forest stands (with large amounts of woody debris) compared to unthinned stands. Barbalat (1996) also found cerambycids to favor clearings 


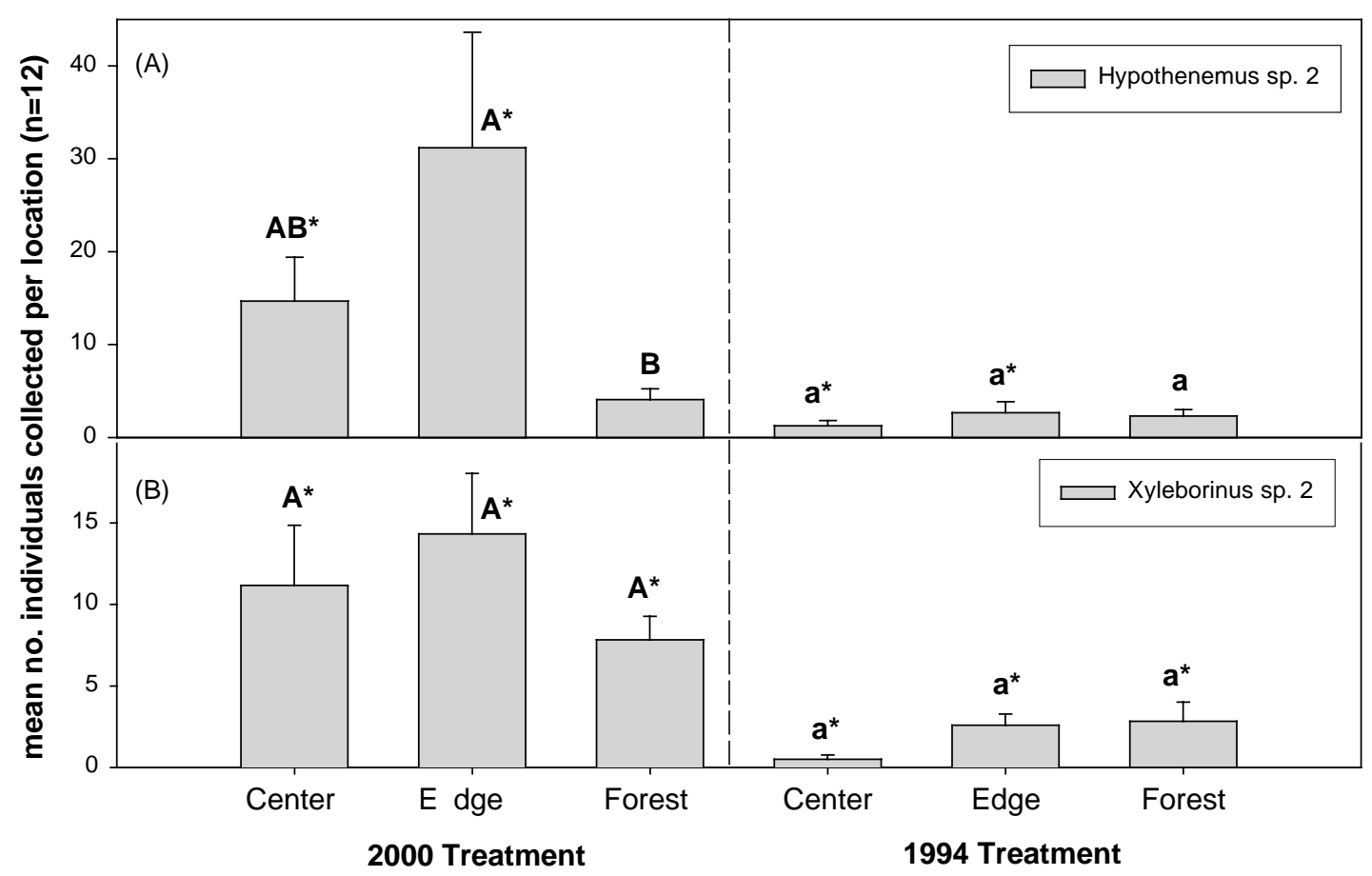

Fig. 7. Mean ( \pm S.E.) abundance of notable scolytine species captured in malaise traps at different locations in bottomland hardwood forest gaps created in 1994 and 2000. Within graphs, bars with the same letter above them are not significantly different (Ryan-Einot-Gabriel-Welsch Multiple Range Test, $P>0.05)$. Asterisks denote significant differences $(P<0.05)$ between the same trap locations (e.g., center vs. center) in old (1994) and new (2000) gaps.

in a managed forest in Switzerland. Another study found that buprestids, cerambycids, and scolytines increased the year following disturbance, but soon declined in number to below undisturbed forest levels (Werner, 2002). Our study shows a similar trend for cerambycids, buprestids, brentids, clerids, scolytines, and platypodines. We found their numbers to be much higher in new canopy gaps with abundant CWD than in the surrounding forest, while the trend for old canopy gaps with very little CWD was the opposite.

Because the creation of new gaps influenced the diversity of woodboring beetles at least $50 \mathrm{~m}$ into the surrounding forest, the traps located in the forest surrounding old gaps may provide a better baseline of bark-beetle and woodborer diversity in undisturbed forest. From this standpoint, recently created gaps and their associated woody debris had, on average, roughly twice the species richness and about 6 times the abundance of beetles than did the forest.

With the exception of their being fewer species in 0.13 ha gaps than in the larger gap sizes, our results show little effect of gap size on the abundance or species richness of wood-dwelling beetles. The larger gaps had proportionally more CWD than did the small gaps, and we expected there to be similar differences in the numbers of wood-dwelling beetles present. Our sampling method (i.e., a malaise trap in the center of each gap) may have missed such differences. The malaise traps may have estimated the beetle density in the immediate vicinity of the traps (which may have been the same regardless of gap size since CWD was evenly distributed across gaps) without accurately portraying differences in the total number of wooddwelling beetles in gaps of each size. Because the sampling radius of our malaise traps is not known we cannot use our data to accurately estimate differences in the abundance of woodborers among different sized gaps.

Not all studies have found an increase in woodborer abundance following disturbance. In a 5-year study, Gutowski (1986) found lower cerambycid diversity and abundance in forests where shelterwood cutting 


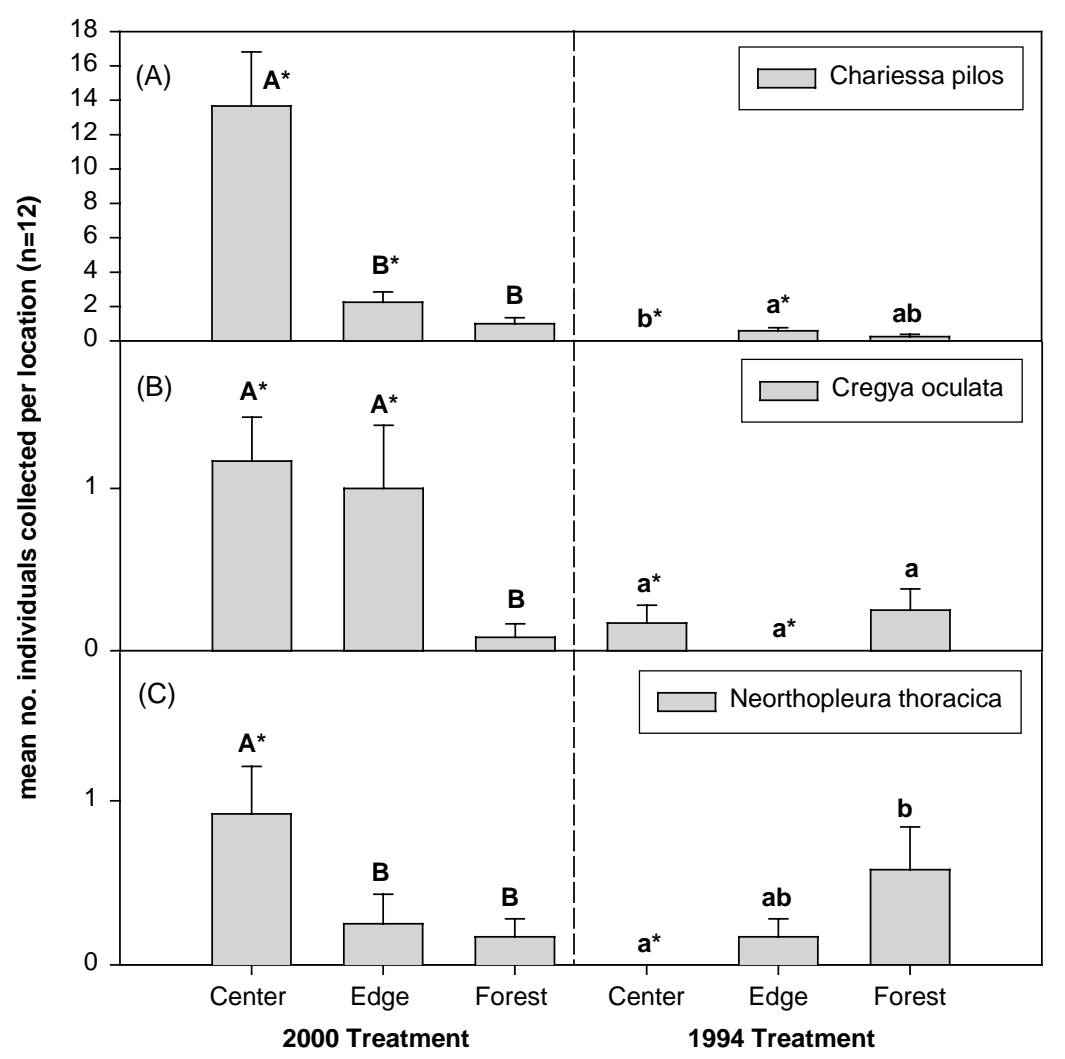

Fig. 8. Mean ( \pm S.E.) abundance of notable clerid species captured in malaise traps at different locations in bottomland hardwood forest gaps created in 1994 and 2000. Within graphs, bars with the same letter above them are not significantly different (Ryan-Einot-Gabriel-Welsch Multiple Range Test, $P>0.05)$. Asterisks denote significant differences $(P<0.05)$ between the same trap locations (e.g., center vs. center) in old (1994) and new (2000) gaps.

was applied compared to unmanaged forests in Poland. Gutowski (1986) observed that in many timber harvesting operations, the slash is burned, but he did not mention the presence or absence of CWD in his study site. If it had been removed, as the author indirectly suggests, then this resource would not have been made available to woodborers.

While preserving some CWD in managed forests is preferable to its removal, we do not suggest that disturbing natural forests would improve wood-dwelling insect habitat. While wood-dwelling insects appear to initially benefit from disturbance, disturbed areas become less favorable with time. As the amount of available CWD decreases, so should the abundance and possibly the diversity of wood-dwelling insects. In our study, 6-year-old gaps had lower abundance and richness of wood boring beetles than did young gaps or the surrounding forest. In disturbed areas, the amount of CWD present, and the associated beetle fauna, depends on how recently the area was disturbed (Grove, 2002; Siitonen, 2001; Spies et al., 1988). Mature, unmanaged forests, in contrast, have a relatively predictable distribution and stable amount of available CWD (Grove, 2002).

Forests that have been mostly undisturbed by humans maintain the most abundant and diverse beetle populations. In Japan, both the diversity and abundance of cerambycids were higher in old-growth forests than in 30- to 70-year-old second-growth forests (Maeto et al., 2002). Furthermore, some species are found only in old forests, underscoring the importance of preserving stands of mature trees (Barbalat, 1996; Gutowski, 1986; Grove, 2002). While we report here several species found only in the clearings, 
they are surely adapted to areas of natural disturbances.

Although unmanaged forests may be preferable from an ecological perspective, the need for timber necessitates its removal. It is important to identify management practices that minimize impact on the local ecosystem. More information is needed to understand the relative value of group selection harvesting compared to other forest management techniques, and how the size of harvest unit affects arthropods. Our results suggest that the smallest gaps ( 0.13 ha) had no fewer wood-dwelling beetles than did the largest gaps ( $0.50 \mathrm{ha})$, and that with but one exception, diversity was not different among gap sizes. We suggest that future studies incorporate a broader range of gap sizes and consider the movement of insects into and out of the gaps. How insects recolonize mature forest after emerging from areas of disturbance remains largely unknown. In this study we found several species to be more common in the forests surrounding new gaps than old gaps, possibly indicating movement from the gap back into the forest.

While further research is needed to understand the long-term implications of forest management, this study clearly demonstrates the importance of preserving CWD created during timber removal. Had the CWD been removed from the new gaps after logging, the diversity and abundance of the woodborers likely would have been well below that of the surrounding forest. Given the evidence from this and past studies of CWD, its preservation should be of central concern to forest management. The degree to which logging disrupts forest ecosystems may be lessened by recognizing the value of the woody debris to many woodinhabiting organisms.

\section{Acknowledgements}

We thank C. Smith for assisting with the identification of specimens, D. Dyer and J. Campbell for helping with field work, and C. Asaro, J. McHugh, and W. Berisford for editing early drafts of the manuscript. Support was provided by the Department of EnergySavannah River Operations Office through the U.S. Forest Service Savannah River under Interagency Agreement DE-A109-00SR22188. This research was funded by the National Research Initiative Competitive Grants Program of the USDA Cooperative
State Research Education and Extension Service (CSREES Grant No. 00-35101-9307).

\section{References}

Anderson, R.S., 2002. Curculionidae. In: Arnett, R.H., Thomas, M.C. (Eds.), American Beetles, vol. 2. pp. 722-815.

Anderson, R.S., Kissinger, D.G., 2002. Brentidae. In: Arnett, R.H., Thomas, M.C. (Eds.), American Beetles, vol. 2. pp. 711-719.

Barbalat, S., 1996. Influence of forest management on three woodeating families in the Areuse Gorges (Canton of Neuchatel Switzerland). Rev. Suisse. Zool. 103, 553-564.

Barbosa, P., Wagner, M.R., 1989. Introduction to Forest and Shade Tree Insects. Academic Press, Inc.

Bellamy, C.L., Nelson, G.H., 2002. Buprestidae. In: Arnett, R.H., Thomas, M.C. (Eds.), American Beetles, vol. 2. pp. 98-112.

Cronin, J.T., Reeve, J.D., Wilkens, R., Turchin, P., 2000. The pattern and range of movement of a checkered beetle predator relative to its bark beetle prey. Oikos 1, 127-138.

Day, R.W., Quinn, G.P., 1989. Comparisons of treatments after an analysis of variance in ecology. Ecol. Mongr. 59, 433-463.

Elton, C.S., 1966. Dying and dead wood. In: The Pattern of Animal Communities. Wiley, New York, pp. 279-305.

Erbilgin, N., Raffa, K.F., 2002. Association of declining red pine stands with reduced populations of bark beetle predators, seasonal increases in root colonizing insects, and incidence of root pathogens. Forest Ecol. Manage. 164, 221-236.

Fellin, D.G., 1980. A review of some interactions between harvesting, residue management, fire, and forest insects and diseases. In: Environmental Consequences of Timber Harvesting in Rocky Mountain Coniferous Forests, Symposium Proceedings. General Technical Report INT-90: U.S. Department of Agriculture, Forest Service.

Fisher, W.S., 1950. A revision of the North American species of beetles belonging to the family Bostrichidae. Misc. Publ. 698 . U.S. Department of Agriculture, Washington, DC, 157 pp.

Grove, S.J., 2002. Saproxylic insect ecology and the sustainable management of forests. Annu. Rev. Ecol. Syst. 33, 1-23.

Guldin, J.M., 1996. The role of uneven-aged silviculture in the context of ecosystem management. WJAF 11, 4-13.

Gutowski, J.M., 1986. Species composition and structure of the communities of longhorn beetles (Coleoptera: Cerambycidae) in virgin and managed stands of Tilio-Carpinetum stachyetosum association in the Bialowieza Forest (NE Poland). J. Appl. Ent. 102, 380-391.

Hagan, J.M., Grove, S.L., 1999. Coarse woody debris. J. Forest. (January), 6-11.

Hanula, J.L., 1996. Relationship of wood-feeding insects and coarse woody debris. In: McMinn, J.W., Crossley Jr., D.A. (Eds.), Biodiversity and Coarse Woody Debris in Southern Forests, Proceedings of the Workshop on Coarse Woody Debris in Southern Forests: Effects on Biodiversity, Athens, GA, October 18-20, 1993. Gen. Tech. Rep. SE-94. U.S. Department of Agriculture, Forest Service, Southern Research Station, Asheville, NC, pp. 55-81. 
Harmon, M.E., Franklin, J.F., Swanson, F.J., Sollins, P., Gregory, S.V., Lattin, J.D., Anderson, N.H., Cline, S.P., Aumen, N.G., Sedell, J.R., Lienkaemper, G.W., Cromack, J.R., Cummins, K.W., 1986. Ecology of coarse woody debris in temperate ecosystems. Adv. Ecol. Res. 15, 133-302.

Hunter, M.L., 1990. Wildlife, Forests, and Forestry. Prentice-Hall, Englewood Cliffs, NJ, USA.

Huston, M.A., 1996. Modeling and management implications of coarse woody debris impacts on biodiversity. In: McMinn, J., Crossley, D.A. (Eds.), Biodiversity and Coarse Woody Debris in Southern Forests. USDA For. Ser. Gen. Tech. Rep. SE-94, Athens, GA.

Kilgo, J.C., 1997. Establishment Report: The Gap Project. U.S. Forest Service Report, Savannah River Institute, $42 \mathrm{pp}$.

Linsley, E.G., 1961. The Cerambycidae of North America. Part I. Introduction, vol. 18. University of California Press, Berkeley, CA.

Maeto, K., Sato, S., Miyata, H., 2002. Species diversity of longhorn beetles in humid warm-temperate forests: the impact of forest management practices on old-growth forest species in southwestern Japan. Biodiv. Conserv. 11, 1919-1937.

Meadows, J.S., Stanturf, J.A., 1997. Silvicultural systems for southern bottomland hardwood forests. Forest Ecol. Manage. 90, 127-140.

Montgomery, M.E., Wargo, P.M., 1983. Ethanol and other hostderived volatiles as attractants to beetles that bore into hardwoods. J. Chem. Ecol. 9, 181-190.

New, K.C., Hanula, J.L., 1998. Effect of time elapsed after prescribed burning in longleaf pine stands on potential prey of the Red-Cockaded Woodpecker. SJAF 22, 175-183.

Opitz, W., 2002. Cleridae. In: Arnett, R.H., Thomas, M.C. (Eds.), American Beetles, vol. 2. pp. 267-280.

Pauley, E.F., Collins, B.S., Smith, W.P., 1996. In: Flynn, K.M. (Ed.), Early Establishment of Cherrybark Oak in Bottomland Hardwood Gaps: Effects of Seed Predation, Gap Size, Herbivory, and Competition. Proceedings of the Southern Forested Wetlands Ecology and Management Conference. Clemson, SC, pp. 132-136.

Reeve, J.D., 2000. Complex emergence patterns in a bark beetle predator. Agric. Forest Entomol. 2, 233-240.
SAS Institute, 1985. SAS Guide for Personal Computers, Version 6th ed. SAS Institute, Cary, NC, 378 pp.

Schroeder, L.M., 1988. Attraction of the bark beetle Tomicus piniperda and some other bark and wood-living beetles to the host volatiles alpha-pinene and ethanol. Entomol. Exp. Appl. 46, 203-210.

Shirt, D.B., 1987. British red data books. 2. Insects. Nat. Conserv. Counc., Peterborough, UK.

Siitonen, J., 2001. Forest management, coarse woody debris and saproxylic organisms: Fennoscandian boreal forests as an example. Ecol. Bull. 49, 11-42.

Solomon, J.D., 1995. Guide to Insect Borers in North American Broadleaf Trees and Shrubs. Agricultural Handbook, vol. 706. U.S. Department of Agriculture, Forest Service, Washington, DC, 735 pp.

Spies, T.A., Franklin, J.F., Thomas, T.B., 1988. Coarse woody debris in Douglas-fir forests of western Oregon and Washington. Ecology 69, 1689-1702.

Twinn, P.F.G., Harding, P.T., 1999. Provisional Atlas of the Longhorn Beetles (Coleooptera, Cerambycidae) of Britain. Nat. Environ. Res. Counc., Abbots Ripton, UK, 96 pp.

Wallace, A.R., 1869. The Malay Archipelago: The Land of the Orang-utan, and the Bird of Paradise. 515 pp.

Warriner, M.D., Nebeker, T.E., Leininger, T.D., Meadows, J.S., 2002. The effects of thinning on beetles (Coleoptera: Carabidae, Cerambycidae) in bottomland hardwood forests. In: Outcalt, K.W. (Ed.), Proceedings of the Eleventh Biennial Southern Silvicultural Research Conference. Gen. Tech. Rep. SRS-48. U.S. Department of Agriculture, Forest Service, Southern Research Station, Asheville, NC, pp. 569-573.

Werner, R.A., 2002. Effect of Ecosystem Disturbance on Diversity of Bark and Wood-Boring Beetles (Coleoptera: Scolytidae, Buprestidae, Cerambycidae) in White Spruce (Picea glauca (Moench) Voss) Ecosystems of Alaska. U.S. Department of Agriculture, Forest Service, Pacific Northwest Research Station, Research Paper PNW-RP-546, pp. 1-15.

Yanega, D., 1996. Field guide to northeastern longhorned beetles (Coleoptera: Cerambycidae). In: Natural History Survey Manual, vol. 6. 